\title{
STUDIES ON AGE DIFFERENGE IN MICE FOR THE ACTIVITY OF DRUG-METABOLIZING ENZYMES OF LIVER MICROSOMES
}

\author{
RYUICHI KATO, AKIRA TAKANAKA AND KIN-ICHI ONODA \\ Department of Pharmacology, National Institute of Hygienic Sciences, Setagaya-ku, Tokyo
} Received for publication June 19, 1970

In previous papers, we reported that the activity of drug-metabolizing enzymes was higher in young female rats than in old female rats and that the duration of hexobarbital anesthesia was shorter in the young females than in the old females (1-3). Moreover, it was observed that the induction of microsomal drug-metabolizing enzymes by phenobarbital was more effective in young rats than in old rats $(4,5)$.

In the present communication, we wish to report the evidence that, in contrast to the results obtained with rats, clear age difference was not observed in the activity of drug-metabolizing enzymes in mice and there was no clear age difference in the induction of drug-metabolizing enzymes by phenobarbital.

\section{MATERIALS AND METHODS}

Male micc of ICR strain were used, unless otherwise specified. Phenobarbital $(80 \mathrm{mg} / \mathrm{kg}$ ) was given intraperitoneally 48 and 24 hours before sacrifice. Pooled liver from 3 mice was used for the preparation of each homogenate. Preparation of postmitochondrial and microsomal fractions was carried out as described in a previous paper (6). The activity of drug-metabolizing enzymes of liver microsomes was assayed as described in the previous paper (6). The hydroxylation of hexobarbital was determined by measuring the disappearance of the substrate according to the method of Cooper and Brodie (7). The N-demethylation of aminopyrine was determined by the formation of 4-aminoantipyrine (La Du et al.) (8). The hydroxylation of aniline was determined by the formation of $p$-aminophenol according to the method described by Kato and Gillette (9). The nitroreduction of $p$-nitrobenzoic acid was determined by measuring the $p$-aminobenzoic acid formed according to the method of Fouts and Brodie (10). NADPH-cytochrome $c$ reductase was determined according to the method of Williams and Kamin (11). NADPH-neotetrazolium reductase was assaycd as described in the previous paper (2). The contents of microsomal protein and cytochrome P-450 were determined by the method of Lowry et al. (12) and Omura and Sato (13), respectively. The duration of hexobarbital anesthesia and zoxazolamine paralysis was determined by the loss of the righting reflex. Strychnine toxicity was evaluated by the convulsion rate and mortality.

\footnotetext{
加藤 隆一・高仲 正・小野田 欽一
} 


\section{RESULTS}

1. The activities of NADPH-linked electron transport system and drug-metabolizing enzymes of liver microsomes

As shown in Table 1 , the ratio of liver weight to body weight was significantly decreased in old mice in accordance with the results obtained with rats (2). The administration of phenobarbital increased the liver wieght in the young mice as well as in the old mice. The magnitude of the percentage increase was similar among the young (5 weeks old), adult (15 weeks old) and old (50 weeks old) mice. There was no clear age difference in the microsomal protein content and the phenobarbital treatment increased the protein content to similar extent in the three groups. These results were of interest, because it has been reported that phenobarbital treatment increased the liver weight

TABLE 1. Liver weight, microsomal protein and cytochrome P-450 content in mice of different age.

\begin{tabular}{|c|c|c|c|c|}
\hline Age & $\underset{\text { treatment }}{\mathbf{P B}}$ & $\begin{array}{l}\text { Liver weight } \\
(\mathrm{g} / 100 \mathrm{~g} \mathrm{BW})\end{array}$ & $\begin{array}{c}\text { Microsomal } \\
\text { protein } \\
\text { (mg/g liver) }\end{array}$ & $\begin{array}{c}\text { Cytochrome } \\
\text { P-450 content } \\
(\mathrm{m} / \mathrm{mole} / \mathrm{mg} \text { protein })\end{array}$ \\
\hline \multirow[t]{2}{*}{5 weeks } & - & $6.08 \pm 0.15$ & $29.3 \pm 0.4$ & $1.08 \pm 0.05$ \\
\hline & + & $\begin{array}{c}7.29 \pm 0.21 \\
(+20 \%)\end{array}$ & $\begin{array}{r}35.5 \pm 0.5 \\
(+21 \%)\end{array}$ & $\begin{array}{l}2.71 \pm 0.13 \\
(+151 \%)\end{array}$ \\
\hline \multirow[t]{2}{*}{ I5 weeks } & - & $5.24 \pm 0.20$ & $30.2 \pm 0.3$ & $1.14 \pm 0.04$ \\
\hline & + & $\begin{array}{c}6.35+0.13 \\
(+21 \%)\end{array}$ & $\begin{array}{r}35.3 \pm 0.6 \\
(+17 \%)\end{array}$ & $\begin{array}{l}2.74 \pm 0.09 \\
(+140 \%)\end{array}$ \\
\hline \multirow[t]{2}{*}{50 wecks } & - & $4.69 \pm 0.20$ & $29.9 \pm 0.2$ & $1.18 \pm 0.05$ \\
\hline & + & $\begin{array}{c}5.80 \pm 0.18 \\
(+24 \%)\end{array}$ & $\begin{array}{r}35.9 \pm 0.3 \\
(+20 \%)\end{array}$ & $\begin{array}{l}2.62 \pm 0.10 \\
(+122 \%)\end{array}$ \\
\hline
\end{tabular}

The results are given as means \pm S.E. of $6-12$ determinations. Pooled livers from 3 mice were used for one determination. The numerals in parentheses indicate the percentage increase by phenobarbital treatment. Phenobarbital $(80 \mathrm{mg} / \mathrm{kg}$ ) was given intraperitoneally 72,48 and 24 hours before sacrifice.

TABLE 2. The activity of NADPH-cytochrome $c$ reductase, NADPH-neotetrazolium reductase and $p$-nitrobenzoic acid nitroreductase in mice of different age.

\begin{tabular}{|c|c|c|c|c|}
\hline Age & $\begin{array}{c}\text { Phenobarbital } \\
\text { treatment }\end{array}$ & $\begin{array}{c}\text { NADPH-cytochrome } \\
c \text { reductase } \\
(\mathrm{m} \mu \mathrm{mole} / \mathrm{mg} \text { protein } / \mathrm{min})\end{array}$ & $\begin{array}{l}\text { NADPH-neotetrazolium } \\
\text { reductase } \\
(\mathrm{m} \mu \mathrm{mole} / \mathrm{mg} \text { protein } / \mathrm{min})\end{array}$ & $\begin{array}{l}p \text {-Nitrobenzoic acid } \\
\text { nitroreduction } \\
(\mathrm{m} \mu \mathrm{mole} / \mathrm{g} / 30 \mathrm{~min})\end{array}$ \\
\hline \multirow[t]{2}{*}{5 weeks } & - & $146 \pm 8$ & $40.5 \pm 2.8$ & $1459 \pm 80$ \\
\hline & + & $\begin{array}{l}261 \pm 12 \\
(+79 \%)\end{array}$ & $\begin{array}{l}87.1 \pm 4.4 \\
(+115 \%)\end{array}$ & $\begin{array}{l}3248 \pm 195 \\
(+122 \%)\end{array}$ \\
\hline \multirow[t]{2}{*}{15 weeks } & - & $152 \pm 7$ & $46.2 \pm 2.9$ & $1580 \pm 121$ \\
\hline & + & $\begin{array}{l}251 \pm 18 \\
(+65 \%)\end{array}$ & $\begin{array}{l}79.9 \pm 3.4 \\
(+73 \%)\end{array}$ & $\begin{array}{l}3140 \pm 185 \\
(+99 \%)\end{array}$ \\
\hline \multirow[t]{2}{*}{50 weeks } & - & $143 \pm 10$ & $44.0 \pm 3.4$ & $1664 \pm 130$ \\
\hline & + & $\begin{array}{l}247 \pm 13 \\
(+73 \%)\end{array}$ & $\begin{array}{l}83.2 \pm 3.0 \\
(+89 \%)\end{array}$ & $\begin{array}{l}2943 \pm 203 \\
(+77 \%)\end{array}$ \\
\hline
\end{tabular}

The results are given as means \pm S.E. of 6-12 determinations. Pooled livers from 3 mice were used for one determination. The numerals in parentheses indicate the percentage increase by phenobarbital treatment. 
and microsomal protein content to a greater extent in young rats than in old rats (5). Moreover, in contrast to the results obtained with rats, there was no clear age difference in the content of cytochrome P-450 and the administration of phenobarbital increased the cytochrome P-450 content to a similar extent in the young, adult and old mice.

As shown in Table 2, the activity of NADPH-cytochrome $c$ reductase, NADPHneotetrazolium reductase and $p$-nitrobenzoic acid nitroreductase was similar in the young, adult and old mice. Moreover, there was no clear age difference in the induction effect of phenobarbital on these reductase activities. These results were also not consistent with those obtained with rats $(2,5)$. These reductase activities were higher in the young rats than in the old rats and the induction effect of phenobarbital was greater in the youngs than in the olds.

Similarly, in contrast to the results observed with rats, there was no clear age difference in the mice concerning the hexobarbital hydroxylation, aminopyrine N-demethylation and aniline hydroxylation (Table 3). The administration of phenobarbital increased the oxidation of drugs by liver microsomes to apparently similar extent in the three different aged groups.

In further experiments, by using female mice, results similar to those observed with the male mice were obtained.

TABLE 3. The hexobarbital hydroxylation, aminopyrine N-demethylation and aniline hydroxylation in mice of different age.

\begin{tabular}{|c|c|c|c|c|}
\hline Age & $\begin{array}{c}\text { Phenobarbital } \\
\text { treatment }\end{array}$ & $\begin{array}{c}\text { Hexobarbital } \\
\text { hydroxylation } \\
(\mathrm{m} \mu \mathrm{mole} / \mathrm{g} / 30 \mathrm{~min})\end{array}$ & $\begin{array}{c}\text { Aminopyrine } \\
\text { N-demethylation } \\
(\mathbf{m} \mu \text { mole/g/30 min) }\end{array}$ & $\begin{array}{c}\text { Aniline } \\
\text { hydroxylation } \\
(\mathrm{m} \mu \mathrm{mole} / \mathrm{g} / 30 \mathrm{~min})\end{array}$ \\
\hline 5 weeks & - & $1252 \pm 68$ & $428 \pm 35$ & $1752 \pm 69$ \\
\hline & + & $\begin{array}{r}2416 \pm 145 \\
(+93 \%)\end{array}$ & $\begin{array}{l}783 \pm 49 \\
(+83 \%)\end{array}$ & $\begin{array}{r}2891 \pm 154 \\
(+65 \%)\end{array}$ \\
\hline 15 weeks & - & $1240 \pm 103$ & $458 \pm 26$ & $1798 \pm 88$ \\
\hline & + & $\begin{array}{r}2120+103 \\
(+71 \%)\end{array}$ & $\begin{array}{l}893 \pm 50 \\
(+95 \%)\end{array}$ & $\begin{array}{c}3003+108 \\
(+67 \%)\end{array}$ \\
\hline 50 weeks & - & $1221 \pm 89$ & $472 \pm 31$ & $1858 \pm 105$ \\
\hline & + & $\begin{array}{r}2222 \pm 201 \\
(+82 \%)\end{array}$ & $\begin{array}{l}774+42 \\
(+64 \%)\end{array}$ & $\begin{array}{r}2768 \pm 218 \\
(+49 \%)\end{array}$ \\
\hline
\end{tabular}

The results are given as means \pm S.E. of 6-12 determinations. Pooled livers from 3 mice were used for one determination. The numerals in parentheses indicate the percentage increase by phenobarbital treatment.

2. The duration of hexobarbital anesthesia and zoxazolamine paralysis and strychnine toxicity The duration of hexobarbital anesthesia was longer in the older mice than in the youngers (Table 4). Similarly, the duration of zoxazolamine paralysis was markedly longer in the old mice than in the young and adult mice. These results were in accordance with the results obtained with rats. However, in contrast to the results obtained with rats, there was no clear age difference in the strychnine toxicity. 
TABLE 4. Hexobarbital anesthesia, zoxazolamine paralysis and strychnine toxicity in mice of different age.

\begin{tabular}{rcrcc}
\hline $\begin{array}{c}\text { Age } \\
\text { (week) }\end{array}$ & $\begin{array}{c}\text { Hexobarbital anesthesia } \\
(\mathrm{min})\end{array}$ & $\begin{array}{c}\text { Zoxazolamine paralysis } \\
(\text { min) }\end{array}$ & & \multicolumn{2}{c}{ Strychnine } \\
Convulsion $(\%)$ & Mortality $(\%)$ \\
\hline 5 & $54 \pm 3(10)$ & $59 \pm 5(10)$ & 50 & 40 \\
15 & $66 \pm 4(10)(+22 \%)$ & $86 \pm 7(10)(+45 \%)$ & 45 & 45 \\
50 & $80 \pm 5(10)(+48 \%)$ & $105 \pm 11(10)(+77 \%)$ & 45 & 40 \\
\hline
\end{tabular}

Number of mice used for hexobarbital anesthesia and zoxazolamine paralysis indicated in parentheses.

Number of mice used for strychnine toxicity was twenty.

Mice were treated intraperitoneally with hexobarbital $(125 \mathrm{mg} / \mathrm{kg})$, zoxazolamine (100 mg/ $\mathrm{kg}$ ) or strychnine $(1.75 \mathrm{mg} / \mathrm{kg})$.

\section{DISGUSSION}

There are some papers which demonstrate the differences of the drug effect and toxicity in aged subject from these in young one in animal experiments and in clinics $(1,3,14-16)$.

In previous papers, we demonstrated that the activity of drug-metabolizing enzymes and NADPH-linked electron transport system in hepatic microsomes was greater in young rats than in old rats and that the duration of hexobarbital anesthesia and carisoprodol paralysis was shorter in the young rats than in the olds $(1,2)$. Moreover, the administration of phenobarbital increased the liver weight, the content of microsomal protein and cytochrome P-450, and the activity of drug-metabolizing enzymes and NADPH-linked electron transport system to a greater extent in the young rats than in the old rats $(1,3)$.

However, in the present experiments, it was observed that there was no clear age difference in the activity of drug-metabolizing enzymes and NADPH-linked electron trasnport system in mice hepatic microsomes.

The duration of hexobarbital anesthesia and zoxazolamine paralysis was longer in the older mice than in the younger ones. These results may be related to the decreased ratio of liver weight to body weight and probably a possible decrease in the rate of hepatic blood flow in the old mice (14-16). On the other hand, there was no marked age difference in the toxicity of strychnine. The reason for the lack of the age difference is not yet clear but the decrease in the sensitivity of the central nervous system to strychnine in the old mice may be a possible factor (15, 17).

The magnitude of the percentage increase in the liver weight, the content of microsomal protein and cytochrome P-450 and the activity of drug-metabolizing enzymes and NADPH-linked electron transport system by the phenobarbital treatment was practically similar among the young, adult and old mice, although old rats showed a slightly smaller percentage of the increase (3).

The mechanism of the species difference in the induction effect of phenobarbital between different aged rats and mice is not clear. It is of interest to note that in mice the lack of the age difference in the activity of drug-metabolizing enzymes was obtained 
in non-treated as well as in the phenobarbital-treated animals. The further studies on other species will be required to determine whether the lack of the age difference in the drug-metabolizing enzymes and the induction effect of phenobarbital was specific for only mice.

\section{SUMMARY}

1. The activity of liver microsomal durg-metabolizing enzymes was investigated in young ( 5 weeks old), adult ( 15 weeks old) and old (50 weeks old) mice.

2. The ratio of liver weight to body weight of the adult and old mice was smaller by $14 \%$ and $23 \%$, respectively, than that of the young mice, but there was no practical age difference in the contents of microsomal protein and cytochrome P-450.

3. The administration of phenobarbital increased the liver wieght and the contents of microsomal protein and cytochrome P-450 to a similar extent in the different aged mice.

4. The activities of NADPH-cytochrome $c$ reductase, NADPH-neotetrazolium reductasc, $p$-nitrobenzoic acid nitroreductase, hexobarbital hydroxylase, aminopyrine $\mathrm{N}$-demethylase and aniline hydroxylase were similar in the different aged mice and the phenobarbital treatment increased all these activities, but the magnitude of the increase was similar in the different aged mice.

5. Thesc results did not agree with the results obtained with rats. These activities were lower in old rats than in young rats and phenobarbital treatment increased the enzyme activities more markedly in the young rats than in the old rats.

6. The duration of hexobarbital anesthesia and zoxazolamine paralysis was longer in the older mice than in the younger mice, but there was no clear age difference in the strychnine toxicity.

\section{REFERENCES}

1) Kato, R., Vassanelli, P., Frontino, G. and Chinesara, E.: Biochem. Pharmac. 13, 1037 (1964)

2) Kato, R. and Takanaka, A.: Jap. J. Pharmac. 18, 381 (1968)

3) Kato, R. and Takanaka, A.: Jap. J. Pharmac. 18, 389 (1968)

4) Kato, R., Chiesara, E. and Frontino, G.: Experientia 17, 520 (1961)

5) Kato, R. and Takanaka, A.: J. Biochem. 63, 406 (1968)

6) Kato, R., Takanaka, A., Takahashi, A. and Onoda, K.: Jap. J. Pharmac. 19, 53 (1969)

7) Cooper, J.R. and Brodie, B.B.: J. Pharmac. exp. Ther, 114, 409 (1955)

8) La Du, B.N., Gaudette, L., Trousof, N. and Brodie, B.B.: J. biol. Chem. 214, 741 (1955)

9) Kato, R. and Gillette, J.R.: J. Pharmac. exp. Ther. 150, 279 (1965)

10) Fouts, J.R. ANd BRodie, B.B.: J. Pharmac. exp. Ther. 119, 197 (1957)

11) Williams, C.H., JR. And Kamin, H.: J. biol. Chem. 237, 587 (1962)

12) Lowry, O.H., Rosebrough, N.J., Farr, A.L. and Randall, R.J.: J. biol. Chem. 193, 265 (1951)

13) Omura, T. and Sato, R.: J. biol, Chem. 239, 2370 (1964)

14) Bender, A.G.: J. Am. Geriatrics Soc. 12, 114 (1964)

15) Bender, A.G.: J. Am. Geriatrics Soc. 15, 68 (1967)

16) Manv, D.E., Jr.: J. Pharm. Sci. 54, 499 (1965)

17) Jacobson, E.: Psychopharmacology and Ageing, Age with a Future, Edited by Hansen, P.E., p. 181, Munksgaard, Copenhagen (1964) 